\title{
Prevalence of Intestinal Helminthiasis among Children with Chronic Neurologic Disorders in University of Nigeria Teaching Hospital (UNTH) Ituku-Ozalla
}

\author{
Uzodimma CE, Ojinnaka NC ${ }^{\star}$, Chukwunedum AU and Anthony NI \\ Department of Paediatrics, University of Nigeria Nsukka, Enugu, Nigeria
}

"Corresponding author: Ojinnaka NC, Department of Paediatrics, University of Nigeria Nsukka, Enugu, Nigeria, Tel: 08030965131; E-mail: ngojimed@yahoo.com Received date: November 05, 2015; Accepted date: January 06, 2016; Published date: January 08, 2016

Copyright: (c) 2016 Uzodimma CE, et al. This is an open-access article distributed under the terms of the Creative Commons Attribution License, which permits unrestricted use, distribution, and reproduction in any medium, provided the original author and source are credited.

\begin{abstract}
Background: Reports show that children with chronic neurological disorders (CNDs) are more prone to helminthic infestation. Major risk factors for high levels of intestinal helminthiasis such as poverty, personal hygiene and poor living conditions are common in developing countries. This study is undertaken to determine the prevalence and pattern of intestinal helminthiasis in children with CNDs in Enugu.

Methods: A total of 130 children with CNDs matched with controls were consecutively recruited. Stool samples of the children were collected and analyzed using the formolether concentration method. Worm load was determined using Stoll's technique. Student t-test was used to compare the mean age of infected subjects and controls and Chi square test for significant association of categorical variables. Statistical tests were done at the $5 \%$ level of significance and p-value less than 0.05 was considered statistically significant.

Results: The prevalence of intestinal helminthiasis among children with CNDs was $8.5 \%$ compared to $12.3 \%$ among the control group $(p=0.309)$. The specific intestinal helminths detected were Ascaris lumbricoides in 10 $(7.7 \%)$ subjects and Trichuris trichiura in one $(0.8 \%)$ subject. The mean age of subjects $(6.5 \pm 3.9$ years) and controls $(6.4 \pm 3.6$ years) infested with helminths compared favourably $(t=0.017, p=0.90)$. There were more males $(63.6 \%)$ than females $(36.4 \%)$ who were infested. All infested study participants had low intensity infestation ranging from 10-60 eggs per gram of faeces. Infestation was more common in the lower and middle socio-economic classes. Method of human waste disposal, personnal hygiene, and habits such as finger sucking, nail-biting and pica did not influence the prevalence of helminthiasis in the study groups.
\end{abstract}

Conclusion: There is a low prevalence of helminthic infestation among children with chronic neurologic disorders in Enugu. This may imply that these children are not neglected in our environment as often reported.

Keywords Paediatric; Ascaris; Autism; Parasitologist; Infections

\section{Introduction}

An approximate two billion people worldwide are infested with one or more soil transmitted helminthes (STHs) [1]. The four main Nematode species of human STH infestations are Ascaris lumbricoides (roundworm), Trichuris trichiura (whipworm), Ancylostoma duodenale and Necator americanus (hookworms). Recent estimates suggest that Ascaris lumbricoides infests about 1221 million people, Trichuris trichiura 795 million and hookworms 740 million [2]. It is also estimated that over 30.7 million school-aged children in Africa are infested with Ascaris lumbricoides, 36.5 million with Trichuris trichiura and 50 million with hookworm [3]. Major risk factors for high levels of intestinal helminthiasis remain poverty, poor environmental sanitation and personal hygiene, lack of potable drinking water, inadequate health care, over-crowding and poor health education [2-4]. Young children are particularly predisposed to heavy infestations with intestinal parasites due to poor immune systems and habitual play in faecally contaminated soil [1]. This has profound negative effect on growth, school attendance and performance, as well as future economic productivity. It also increases their susceptibility to other illnesses like malaria and tuberculosis [1].
Chronic neurologic disorders (CNDs) comprise a heterogeneous group of disorders including neuromuscular disorders which mainly affect the body's nervous system and have lasted for or are virtually certain to last for one year and produce at least one type of consequence namely functional limitation, reliance on compensatory assistance for functioning, or increased service [5]. While children are generally susceptible to intestinal parasites, CNDs have been reported to be more prone to these infestations.6 Studies have shown varying prevalence of intestinal helminthiasis in children who have CNDs $[6,7]$. Nwaneri et al. reported a prevalence rate of $31 \%$ among children with CNDs, while Mohamed et al reported a prevalence rate as high as $76.67 \%$ in mentally retarded subjects in Egypt [6,7]. In spite of the public health significance of STHs, there is paucity of data on intestinal helminthiasis among children with CNDs especially in Nigeria. This study was therefore conducted to determine the prevalence and pattern of intestinal helminthiasis among children with CNDs in Enugu, Nigeria and possible association with known risk factors for helminthiasis in children. 
Citation: Uzodimma CE, Ojinnaka NC, Chukwunedum AU, Anthony NI (2016) Prevalence of Intestinal Helminthiasis among Children with Chronic Neurologic Disorders in University of Nigeria Teaching Hospital (UNTH) Ituku-Ozalla. J Neurol Disord 4: 258. doi: $10.4172 / 2329-6895.1000258$

Page 2 of 6

\section{Materials and Methods}

\section{Study design and duration}

This was a hospital based cross-sectional study carried out from 15th February 2013 to 31st August 2013 at the University of Nigeria Teaching Hospital (UNTH), Ituku-Ozalla, Enugu state.

\section{Study population}

The average population of patients with chronic neurologic disorders attending the Paediatric Neurology Clinic in UNTH ItukuOzalla over a period of one year is 200 [8]. The subjects were children diagnosed with CNDs and on follow-up visits at the Paediatric Neurology Clinic and had not taken anti-helminthic drugs for three months prior to the study. The primary diagnoses for the various CNDs recruited were made based on the following criteria:

- Epilepsy - history and findings on electroencephalograph $[9,10]$.

- Cerebral palsy - history and examination findings [11,12].

- Mental retardation - scores obtained from the draw-a-person test (DAPT). The DAPT is a measure of visual-spatial-motor conception and execution which has a correlation of 0.62 with Stanford-Binet test of intelligence as well as the Wechsler's Intelligence Scale for Children (WISC), validated and widely used in our environment [13-15].

- Attention-deficit hyperactivity disorder (ADHD) - based on internationally accepted criteria [16].

- Autism - based on internationally accepted criteria [14].

The control group was recruited from the Children Out-Patient (CHOP) Clinic of the hospital. They had acute problems such as malaria, respiratory infections, skin infections etc with no chronic neurologic disorder or any other chronic condition. They were also matched for age, sex and socio-economic status with the subjects and had not taken anti-heminthic drugs for three months prior to the study.

Ethical approval of the Health Research and Ethics Committee of the hospital was obtained before commencement of the study. Thumb printed and/or signed informed consent was also obtained from the parents/guardians of the study participants.

Subjects who met the inclusion criteria were recruited consecutively on clinic days until the desired sample size was obtained. Information regarding age, gender, educational status and occupation of parents and subject's clinical history were obtained using an interviewer administered questionnaire. Socio-economic classification was based on the criteria used by Olusanya et al. [17].

\section{Stool collection and analysis}

Instructions were given to the parents/guardians/older participants to collect fresh (early morning) stool samples into a clean, widemouthed, leak-proof and properly labeled specimen container using applicator sticks (both provided for each subject). For those unable to produce stool sample, a subsequent appointment was scheduled. Each sample container had $10 \%$ formol water for preservation of any helminth eggs in stool. These stool samples were collected and analyzed before the close of work on the same day of collection using the formol-ether concentration method [18]. Stool slides were subsequently prepared and read for every analyzed sample. Stool analysis, slide preparation and reading were done by an experienced medical parasitologist. To ensure consistency of readings, second readings were performed by another experienced medical parasitologist in $20 \%$ of randomly selected slides, as described by Andrade et al. [19]. Helminth eggs were identified based on characteristic morphological features for each species using microscopic examination at $\mathrm{x} 10$ objective (or $\mathrm{x} 40$ objective if necessary). Identification of at least one helminth ovum on a prepared slide was taken as positive. Where no ovum was identified, it was described as negative. The worm load was determined using Stoll's technique for counting helminth eggs [18] and reported as number of eggs per gram (or epg) of faeces. Grading of the intensity of infestation was based on WHO criteria [20]. In addition, samples were examined as fresh as possible so that hookworm eggs might be identified before they hatch [21].

\section{Data analysis}

Data were analyzed using the Statistical Package for Social Sciences (SPSS) version 20.0 (Chicago, Illinois, USA). Kappa test was used to determine the agreement in identification of helminth ova between the parasitologist and the researchers. Descriptive statistics were used to summarize quantitative variables (such as age), while qualitative variables (such as socioeconomic class) were summarized using proportions. The Student t-test was used to compare the mean age of infested subjects and controls. Chi square or Fisher's exact test was used to test for significant association of categorical variables. All statistical tests were done at the $5 \%$ level of significance and a p-value less than 0.05 was considered statistically significant.

\section{Results}

\section{Study participants}

A total of 260 children made up of 130 subjects and 130 controls were studied. The median age was 6 years and 7 years for subjects and controls respectively (range 1-18 years). There were 82 males (63.1\%) and 48 females $(36.9 \%)$ for the two study groups giving a male-tofemale ratio of 1.7:1. Among both groups, 25 (19.2\%), 69 (53.1\%), and $36(27.7 \%)$ children were in the upper, middle and lower social classes respectively.

Epilepsy was the most common disorder and was documented in 86 (66.2\%) patients. Twenty-five (19.2\%) patients had cerebral palsy (CP) and the rest were mental retardation (MR) 12 (9.2\%), delayed speech, three $(2.3 \%)$, autism, three $(2.3 \%)$, and attention-deficit hyperactivity disorder (ADHD), one $(0.8 \%)$.

\section{Intestinal helminthiasis in subjects and controls}

\begin{tabular}{|l|l|l|l|l|l|}
\hline Helminth species & & $\begin{array}{l}\text { Controls } \\
\mathbf{n}=130(\%)\end{array}$ & $\mathbf{X} 2$ & $\mathbf{P}$ \\
\hline Ascariasis & $10(7.7)$ & $11(8.5)$ & 0.052 & 1 & 0.82 \\
\hline Trichuriasis & $1(0.8)$ & $5(3.8)$ & 2.730 & 1 & 0.10 \\
\hline $\begin{array}{l}\text { Prevalence of } \\
\text { intestinal } \\
\text { helminthiasis }\end{array}$ & $11(8.5)$ & $16(12.3)$ & 1.033 & 1 & 0.33 \\
\hline
\end{tabular}

Table 1: Specie specific prevalence of intestinal helminthiasis among study participants. 
Citation: Uzodimma CE, Ojinnaka NC, Chukwunedum AU, Anthony NI (2016) Prevalence of Intestinal Helminthiasis among Children with Chronic Neurologic Disorders in University of Nigeria Teaching Hospital (UNTH) Ituku-Ozalla. J Neurol Disord 4: 258. doi: $10.4172 / 2329-6895.1000258$

Page 3 of 6

Table 1 shows the prevalence and specie specific prevalence of intestinal helminthiasis of subjects and controls. Eleven subjects (8.5\%) and 16 controls $(12.3 \%)$ had intestinal helminthiasis $\left(\chi^{2}=1.033, \mathrm{p}=\right.$ 0.31). Ascaris lumbricoides was found in 10 subjects (7.7\%) and 11 controls (8.5\%), while Trichuris trichiura was reported in one subject $(0.8 \%)$ and five controls (3.8\%). The difference between the number of subjects and controls infested with Ascaris lumbricoides $(\mathrm{p}=0.82)$ and Trichuris trichiura $(\mathrm{p}=0.10)$ was not statistically significant. There were no cases of polyparasitism. All of the study participants infested with intestinal helminths had light (or low intensity) infestation ranging from 10-60 eggs per gram of faeces.

\begin{tabular}{|c|c|c|c|c|c|}
\hline \multirow[t]{2}{*}{ Characteristic } & Intestinal & Helminths & \multirow[t]{2}{*}{$x^{2}$} & \multirow[t]{2}{*}{ df } & \multirow[t]{2}{*}{$\mathbf{p}$} \\
\hline & $\begin{array}{l}\text { Subjects n } \\
(\%)\end{array}$ & $\begin{array}{l}\text { Controls } \quad n \\
(\%)\end{array}$ & & & \\
\hline \multicolumn{6}{|l|}{ Age group } \\
\hline $1-4$ & $3(27.3)$ & $5(31.25)$ & 4.872 & 2 & 0.7 \\
\hline $5-9$ & $7(63.6)$ & $8(50.0)$ & & & 2 \\
\hline$\geq 10$ & $1(9.1)$ & $3(18.75)$ & & & \\
\hline \multicolumn{6}{|l|}{ Sex } \\
\hline Male & $7(63.6)$ & $10(62.5)$ & 0.000 & 1 & 1.0 \\
\hline Female & $4(36.4)$ & $6(37.5)$ & & & \\
\hline
\end{tabular}

Socioeconomic class

\begin{tabular}{|l|l|l|l|l|l|}
\hline Upper & $2(18.2)$ & $4(25.0)$ & & & 0.8 \\
\hline Middle & $4(36.4)$ & $9(56.25)$ & 0.319 & 2 & 5 \\
\hline Lower & $5(45.4)$ & $3(18.75)$ & & & \\
\hline Total & $11(100.0)$ & $16(100.0)$ & & & \\
\hline
\end{tabular}

Table 2: Socio-demographic characteristics of study participants with intestinal.
The socio-demographic characteristics of study participants with helminthes infestation are shown in Table 2. The mean age of study participants infested with intestinal helminthes was $6.4 \pm 3.9$ years and $6.4 \pm 3.6$ years for subjects and controls respectively $(\mathrm{t}=0.017, \mathrm{p}=$ 0.90 ). Children in the age group 5-9 years were infected more than other age groups.

There were more males than females infested with intestinal helminthes in both subjects and controls. However, the difference between the number infected with intestinal helminthiasis for genders was not statistically significant $\left(\chi^{2}=0.000, \mathrm{p}=1.0\right)$.

Majority of the subjects (45.4\%) with intestinal helminthiasis were from the lower socio-economic class while that of the controls (56.3\%) were from the middle socio-economic class. The difference in the socio-economic class was not statistically significant $\left(\chi^{2}=0.319, \mathrm{p}=\right.$ $0.85)$.

\section{Risk factors for intestinal helminthiasis}

Method of human waste disposal: Method of human waste disposal among subjects and control with or without helminthic infestation is shown in Table 3. Water cistern was the most common mode of human waste disposal among the subjects (57.7\%) and controls (61.5\%). Among the study participants who disposed their human waste by water cistern method, four (5.3\%) out of 75 subjects, compared to nine $(11.25 \%)$ out of 80 controls, were infested with intestinal helminths $\left(\chi^{2}=1.76, \mathrm{p}=0.18\right)$.

Hand-washing practices: Table 4 shows the hand-washing practices among study participants. Seven out of 11 subjects (63.6\%) and 12 out of 16 controls $(75.0 \%)$ infested with intestinal helminths washed their hands after defaecating while four subjects $(36.4 \%)$ and four controls (25.0\%) each from the same group infested with helminths did not. The difference in hand-washing practices after defecation and prevalence of intestinal helminthiasis was not statistically significant for subjects $\left(\chi^{2}=0.130, \mathrm{p}=0.72\right)$ and controls $\left(\chi^{2}=3.845, \mathrm{p}=0.05\right)$ (Tables 3 and 4 ).

\begin{tabular}{|c|c|c|c|c|c|c|c|}
\hline \multirow[t]{2}{*}{ Risk factor } & \multicolumn{2}{|c|}{ Subject n (\%) } & \multicolumn{2}{|c|}{ Control n (\%) } & \multirow[t]{2}{*}{$x^{2}$} & \multirow[t]{2}{*}{ df } & \multirow[t]{2}{*}{ p } \\
\hline & Infested & Not Infested & Infested & Not Infested & & & \\
\hline \multicolumn{8}{|l|}{ Waste disposal } \\
\hline Water Cistern & $4(36.3)$ & 71 (59.6) & $9(56.3)$ & $71(62.3)$ & 1.76 & 3 & 0.18 \\
\hline Pit latrine & $2(18.2)$ & $14(11.8)$ & $1(6.2)$ & $5(4.4)$ & 0.06 & 3 & 0.80 \\
\hline Potty/nappy & $3(27.3)$ & $20(16.8)$ & $4(25.0)$ & $30(26.3)$ & 0.02 & 3 & 0.89 \\
\hline Bush & $2(18.2)$ & $14(11.8)$ & $2(12.5)$ & $8(7.0)$ & 0.27 & 3 & 0.61 \\
\hline Total & $11(100.0)$ & $119(100.0)$ & $16(100.0)$ & $114(100.0)$ & & & \\
\hline
\end{tabular}

Table 3: Method of human waste disposal among subjects and control with or without helminthic infestation.

\begin{tabular}{|l|l|l|l|l|l|l|l|l|l|l|}
\hline Risk factor & \multicolumn{3}{|l|}{ Subjects $\mathbf{n}(\%)$} & \multicolumn{3}{l|}{ Control $\mathbf{n}(\%)$} & \multicolumn{2}{l|}{} \\
\hline $\begin{array}{l}\text { Hand-washing } \\
\text { Practices }\end{array}$ & Infested & Not Infested & $X 2$ & df & $p$ & Infested & Not Infested & $x^{2}$ & df & $p$ \\
\hline
\end{tabular}


Citation: Uzodimma CE, Ojinnaka NC, Chukwunedum AU, Anthony NI (2016) Prevalence of Intestinal Helminthiasis among Children with Chronic Neurologic Disorders in University of Nigeria Teaching Hospital (UNTH) Ituku-Ozalla. J Neurol Disord 4: 258. doi: $10.4172 / 2329-6895.1000258$

Page 4 of 6

\begin{tabular}{|l|l|l|l|l|l|l|l|l|l|l|}
\hline Yes & $7(63.6)$ & $82(68.9)$ & 0.13 & 1 & 0.75 & $12(75.0)$ & $104(91.2)$ & 3.85 & 1 & 0.05 \\
\hline No & & & & & & $4(25.0)$ & $10(8.8)$ & & \\
\hline Total & $11(100.0)$ & $37(31.1)$ & & & & $16(100.0)$ & $114(100.0)$ & & \\
\hline
\end{tabular}

Table 4: Hand-washing practices after defaecation among study population with and without intestinal helminthiasis.

Habits: Table 5 shows the habits among subjects and controls with intestinal helminthiasis. Out of the 21, 24 and 23 subjects who had the habits of finger sucking, pica and nail-biting respectively, one $(4.8 \%)$, two $(8.3 \%)$ and two $(8.7 \%)$ were infested with intestinal helminths compared to $20\left(\chi^{2}=0.443, \mathrm{p}=0.51\right), 22\left(\chi^{2}=0.001, \mathrm{p}=0.98\right)$ and 21 $\left(\chi^{2}=0.002, p=0.96\right)$ respectively who were not (Table 5$)$.

\begin{tabular}{|c|c|c|c|c|c|c|c|c|c|c|}
\hline \multirow[b]{2}{*}{$\begin{array}{l}\text { Risk } \\
\text { factor }\end{array}$} & \multicolumn{2}{|c|}{ Subjects (n \%) } & \multirow[b]{2}{*}{$x^{2}$} & \multirow[b]{2}{*}{ df } & \multirow[b]{2}{*}{$P$} & \multicolumn{2}{|c|}{ Control (n \%) } & \multirow[b]{2}{*}{$x^{2}$} & \multirow[b]{2}{*}{ df } & \multirow[b]{2}{*}{$\mathrm{p}$} \\
\hline & $\begin{array}{l}\text { Infeste } \\
\text { d }\end{array}$ & $\begin{array}{l}\text { Not } \\
\text { infeste } \\
\text { d }\end{array}$ & & & & $\begin{array}{l}\text { Infeste } \\
d\end{array}$ & $\begin{array}{l}\text { Not } \\
\text { infeste } \\
\text { d }\end{array}$ & & & \\
\hline \multicolumn{11}{|c|}{ Finger sucking } \\
\hline Yes & $1(9.1)$ & \begin{tabular}{|l}
20 \\
$(16.8)$
\end{tabular} & 0.44 & 1 & $\begin{array}{l}0.5 \\
1\end{array}$ & $1(6.3)$ & $\begin{array}{l}13 \\
(11.4)\end{array}$ & $\begin{array}{l}0.38 \\
8\end{array}$ & 1 & $\begin{array}{l}0.5 \\
3\end{array}$ \\
\hline No & $\begin{array}{l}10 \\
(90.9)\end{array}$ & \begin{tabular}{|l}
99 \\
$(83.2)$
\end{tabular} & & & & $\begin{array}{l}15 \\
(93.7)\end{array}$ & $\begin{array}{l}101 \\
(88.6)\end{array}$ & & & \\
\hline \multicolumn{11}{|c|}{ Nail-biting } \\
\hline Yes & $\begin{array}{l}2 \\
(18.2)\end{array}$ & \begin{tabular}{|l}
22 \\
$(18.5)$
\end{tabular} & & & & $\begin{array}{l}2 \\
(12.5)\end{array}$ & $\begin{array}{l}27 \\
(23.7)\end{array}$ & $\begin{array}{l}1.01 \\
3\end{array}$ & 1 & $\begin{array}{l}0.3 \\
1\end{array}$ \\
\hline No & $\begin{array}{l}9 \\
(81.8)\end{array}$ & $\begin{array}{l}97 \\
(81.5)\end{array}$ & $\begin{array}{l}0.00 \\
1\end{array}$ & 1 & $\begin{array}{l}0.9 \\
8\end{array}$ & $\begin{array}{l}14 \\
(87.5)\end{array}$ & $\begin{array}{l}87 \\
(76.3)\end{array}$ & & & \\
\hline \multicolumn{11}{|l|}{ Pica } \\
\hline Yes & $\begin{array}{l}2 \\
(18.2)\end{array}$ & \begin{tabular}{|l}
21 \\
$(17.6)$
\end{tabular} & $\begin{array}{l}0.00 \\
2\end{array}$ & 1 & $\begin{array}{l}0.9 \\
6\end{array}$ & NA & & & & \\
\hline No & $\begin{array}{l}9 \\
(81.8)\end{array}$ & \begin{tabular}{|l|}
98 \\
$(82.4)$
\end{tabular} & & & & NA & & & & \\
\hline \multicolumn{11}{|c|}{ Toilet-Trained } \\
\hline Yes & $\begin{array}{l}7 \\
(63.6)\end{array}$ & \begin{tabular}{|l}
95 \\
$(79.8)$
\end{tabular} & $\begin{array}{l}1.56 \\
3\end{array}$ & 1 & $\begin{array}{l}0.2 \\
1\end{array}$ & $\begin{array}{l}14 \\
(87.5)\end{array}$ & $\begin{array}{l}106 \\
(93.0)\end{array}$ & $\begin{array}{l}0.59 \\
4\end{array}$ & 1 & $\begin{array}{l}0.4 \\
4\end{array}$ \\
\hline No & $\begin{array}{l}4 \\
(36.4)\end{array}$ & $\begin{array}{l}24 \\
(20.2)\end{array}$ & & & & $\begin{array}{l}2 \\
(12.5)\end{array}$ & $8(7.0)$ & & & \\
\hline Total & $\begin{array}{l}11 \\
(100.0)\end{array}$ & \begin{tabular}{|l}
119 \\
$(100.0)$
\end{tabular} & & & & $\begin{array}{l}16 \\
(100.0)\end{array}$ & $\begin{array}{l}114 \\
(100.0)\end{array}$ & & & \\
\hline
\end{tabular}

Table 5: Habits of the study population with and without intestinal helminthiasis.

Among the 102 subjects who were toilet trained, seven (6.9\%) were infested with intestinal helminths compared to 95 who were not $\left(\chi^{2}=\right.$ $1.563, \mathrm{p}=0.21)$. Also out of the 14 and 29 controls who had the habits of finger sucking and nail-biting, one (7.1\%) and two (6.9\%) were infested with intestinal helminths respectively compared to 13 and 27 for those who were not infected with $\chi^{2}=0.388, p=0.53$ and $\chi^{2}=$ $1.013, p=0.31$ respectively. Similarly, among the 120 controls who were toilet trained, $14(11.7 \%)$ were infested with intestinal helminths compared to 106 who were not $\left(\chi^{2}=0.594, p=0.44\right)$.

\section{Discussion}

The present study shows that the prevalence rate of intestinal helminthiasis among children with CNDs is $8.5 \%$. This is lower than $31 \%$ reported by Nwaneri et al. [6] who studied a similar population in Benin, South-South Nigeria. The marked difference in the prevalence from the two centres can be attributed to the fact that two-thirds of the subjects in the present study comprised of epileptics while $58 \%$ of the subjects in the study from Benin [6] were children with CP. Children with epilepsy have better social and behavioural adaptation compared with those with CP and MR [22]. Children with epilepsy can therefore, compare favourably with normal children. Additionally, $7.7 \%$ of the subjects in the study by Nwaneri et al. [6] had MR. Mental retardation and $\mathrm{CP}$ predispose children to poor personal hygiene and pica which are known risk factors for infestation with STHs.15 Interestingly too, Ekpeyong and Eyo in a recent study in Ibagwa, Itchi, Ovoko, Iheaka, Unadu and Iheakpu-Awka communities also in South-East Nigeria like Enugu, reported a prevalence of $8.2 \%$ of STHs among normal children [23]. This may suggest an overall lower prevalence of STHs in SouthEast Nigeria. There are multiple explanations for this lower prevalence. Firstly, there have been frequent dewormimg exercises of children in the South-East part of the country and secondly, there have also been improved sanitation and water supply. Hence low prevalence rates in the general population explain lower rates among at risk individuals as documented in our study. Nwaneri et al. [6] analyzed stool samples using the Kato-Katz method, while this present study used the formolether concentration technique similar to the Ebonyi study [23]. The latter method concentrates helminth ova more from stool than the former thereby aiding better identification [24,25]. Also, behavioural risk factors for helminthiasis such as pica, nail-biting, and finger sucking was high in the subjects reported by Nwaneri in Benin compare to the present study. This could be responsible for differences in prevalence rates [26].

In this study, Ascaris lumbricoides was the most prevalent Helminth species followed by Trichuris trichiura. This is similar to findings from other studies Eggs of Ascaris lumbricoides possess an adhesive covering which enhances their attachment to many surfaces making them available for hand-to-mouth transmission in individuals who wash their hands infrequently [2,6,7,23,27-30]. This study neither isolated other Helminth species nor did it record polyparasitism. This could be due to the reduction in risk factors for infestation. The similarity in prevalence of STHs in the subjects and controls in this study is different from findings in the studies from Benin [6] and Egypt [7]. A number of factors could have contributed to this. The absence of statistically significant risk factors for helminthiasis for both groups in the present study compared to the Benin study may be responsible for the comparable prevalence rates. The study in Benin reported that subjects with CNDs had statistically significant risk factors compared to controls. This probably led to the statistically higher prevalence of helminthiasis in their subjects than controls. Finger-sucking and pica are known risk factors for helminthic infestation [26]. These habits enhance transmission of STHs through 
Citation: Uzodimma CE, Ojinnaka NC, Chukwunedum AU, Anthony NI (2016) Prevalence of Intestinal Helminthiasis among Children with Chronic Neurologic Disorders in University of Nigeria Teaching Hospital (UNTH) Ituku-Ozalla. J Neurol Disord 4: 258. doi: $10.4172 / 2329-6895.1000258$

Page 5 of 6

the faeco-oral route. When human waste (which may harbour helminth eggs) is not properly disposed of, it will contaminate soil and/or water. Furthermore, unclean hands and surfaces in residences still serve as sources of transmission of STHs.

Despite the marked difference in prevalence rate of helminthiasis between our study and that from Benin, the mean age for helminthiasis among children with CNDs from both studies compares favourably. Similarly, the peak age group for helminthiasis in both studies was comparable. Studies among normal children also report highest prevalence of helminthiasis within this age group (5-9 years) [27-29]. This agrees with the fact that $60 \%$ of helminthic infestations occur in children [30]. Young children are more predisposed to infestation with STHs than older children, adolescents and adults because they habitually play in faecally contaminated soil and have immature immune systems $[1,31]$.

There were more males than females with intestinal helminthiasis from this study. Males are known to be more adventurous. They are more likely than females to come in contact with soil (contaminated with helminth eggs) and therefore have the greater risk of infestation with STHs.

This study shows that helminthiasis is a disease associated with poverty as evidenced by the greater proportion of STHs among the lower social class of the subject group. This has been reported by several authors in studies among individuals with and without CNDs $[6,29]$. The poor living conditions (poor sanitation, unsafe drinking water) which economically disadvantaged individuals face is a possible explanation for the high proportion with helminthiasis amongst those from lower socio-economic class. Ignorance to the simple hygiene tips (such as frequent hand-washing after defaecation and before eating) and poor habit which is evidence in this study also plays a role.

\section{Conclusion}

There was a low prevalence of helminthic infestation among children with chronic neurologic disorders in Enugu. Behavioural modification and improvements in personal hygiene and waste disposal are recommended for control of soil-transmitted helminthiasis in children.

\section{References}

1. Bethony J, Brooker S, Albonico M, Geiger SM, Loukas A, et al. (2006) Soil-transmitted helminth infections: ascariasis, trichuriasis, and hookworm. Lancet 367: 1521-1532.

2. de Silva NR, Brooker S, Hotez PJ, Montresor A, Engels D, et al. (2003) Soil-transmitted helminth infections: updating the global picture. Trends Parasitol 19: 547-551.

3. Brooker S, Clements AC, Bundy DA (2006) Global epidemiology, ecology and control of soil-transmitted helminth infections. Adv Parasitol 62: 221-261.

4. Asaolu SO, Ofoezie IE (2003) The role of health education and sanitation in the control of helminth infections. Acta Trop 86: 283-294.

5. Blanton L, Peacock G, Cox C, Jhung M, Finelli L, et al. (2012) Neurologic disorders among pediatric deaths associated with the 2009 pandemic influenza. Pediatr 130: 390-396.

6. Nwaneri DU, Ibadin MO, Ofovwe GE, Sadoh AE (2013) Intestinal helminthiasis in children with chronic neurological disorders in Benin City, Nigeria: intensity and behavioral risk factors. World J Pediatr 9: 152-157.
7. Mohamed NH, Salem SA, Azab ME, Bebars MA, Khattab HM, et al. (1991) Parasitic infections associated with mental retardation in Egypt. J Egypt Soc Parasitol 21: 319-331.

8. Okoro J (2011) Immunization Status of children with chronic neurologic disorders seen in UNTH, Enugu. National Post-Graduate Medical College of Nigeria Dissertation.

9. Johnston MV (2010) Seizures in childhood. In: Kliegman RM, Behrman RE, Jenson HB, Stanton BF (eds.) (19thedn) Nelson textbook of Pediatrics, Saunders Elsevier. Philadelphia.

10. Engel J (2001) A proposed diagnostic scheme for people with epileptic seizures and with epilepsy: report of the ILAE task force on classification and terminology. Epilepsia 42: 96-803.

11. Bax M, Goldstein M, Rosenbaum P, Leviton A, Paneth M (2005) Proposed definition and classification of cerebral palsy, April 2005. Dev Med Child Neurol 47: 571-576.

12. Hagberg B, Hagberg G (1993) The origins of cerebral palsy. In: David TJ (Ed). Recent advances in paediatrics (11thedn) Edinburgh: Churchhill Livingstone. 67-83.

13. Ebigbo PO, Izuora GI (1981) Draw-a-person-test - standardization, validation and guidelines for use in Nigeria. Enugu: Chuka Printing Company Ltd.

14. Michael B (1994) Diagnostic and Statistical Manual of Mental Disorders (4thedn) American Psychiatric Association, Washington DC.

15. Olusanya O, Okpere E, Ezimokhai M (1985) The importance of social class in voluntary fertility control in a developing country. W Afr J Med 4: 205-11.

16. Albonico M, Chwaya HM, Montresor A, Stolfzfus RJ, Tielsch JM, et al. (1997) Parasitic infections in Pemba Island school children. East Afr Med J 74: 294-298.

17. Cheesbrough M (2005) Parasitological tests. In District laboratory practice in tropical countries, Part 1. Cambridge University Press, United Kingdom.

18. Melvin MA, Chiodini PL, Engback K, Heuck CC, Houane L et al, (1991) WHO Basic laboratory methods in medical parasitology. Geneva: WHO. USA.

19. Andrade C, Alava T, De Palacio IA, Del Poggio P, Jamoletti C, et al. (2001) Prevalence and intensity of soil-transmitted helminthiasis in the city of Portoviejo (Ecuador). Mem Inst Oswaldo Cruz 96: 1075-1079.

20. Ash LR, Orihel TC, Savioli L (1994) Bench aids for the diagnosis of intestinal parasites. Geneva: WHO, USA.

21. WHO Expert Committee (2002) Prevention and control of schistosomiasis and soil-transmitted helminthiasis. World Health Organ Tech Rep Ser 912: i-vi, 1-57, back cover.

22. McDermott S, Coker AL, Mani S, Krishnaswami S, Nagle RJ, et al. (1996) A population-based analysis of behavior problems in children with cerebral palsy. J Pediatr Psychol 21: 447-63.

23. Ekpenyong EA, Eyo JE (2008) Prevalence of intestinal helminths infections among schooling children in tropical semi urban communities. Anim Res Int 5: 804-10.

24. Cringoli G, Rinaldi L, Maurelli MP, Utzinger J (2010) FLOTAC: new multivalent techniques for qualitative and quantitative copromicroscopic diagnosis of parasites in animals and humans. Nat Protoc 5: 503-515.

25. Allen AVH, Ridley DS (1970) Further observations on the formol-ether concentration technique for faecal parasites. J Clin Pathol 23: 545-546.

26. Nwaneri DU, Ibadin MO, Ofovwe GE, Sadoh AE (2013) Intestinal helminthiasis in children with chronic neurological disorders in Benin City, Nigeria: intensity and behavioral risk factors. World J Pediatr 9: 152-157.

27. Uneke CJ, Eze KO, Oyibo PG, Azu NC, Ali E (2007) Soil-transmitted helminth infection in school children in south-eastern Nigeria: the public health implication. Internet J Third World Med 4: 1.

28. Nmor JC, Onojafe JO, Omu BA (2009) Anthropogenic indices of soiltransmitted helminthiasis among children in Delta state, Southern Nigeria. Iranian J Public Health 38: 31-38. 
Citation: Uzodimma CE, Ojinnaka NC, Chukwunedum AU, Anthony NI (2016) Prevalence of Intestinal Helminthiasis among Children with Chronic Neurologic Disorders in University of Nigeria Teaching Hospital (UNTH) Ituku-Ozalla. J Neurol Disord 4: 258 . doi: $10.4172 / 2329-6895.1000258$

Page 6 of 6

29. Damen JG, Luka J, Biwan EI, Lugos M (2011) Prevalence of Intestinal Parasites among Pupils in Rural North Eastern, Nigeria. Niger Med J 52: 4-6.

30. World Health Organization (2009) Neglected tropical diseases: hidden successes, emerging opportunities. Geneva, USA.
31. Crompton DWT (1989) Biology of Ascaris lumbricoides. In: Crompton DWT, Nesheim MC, Pawlowski ZS (eds.) Ascariasis and its prevention and control. London: Taylor \& Francis. 